\title{
MOLLUSCA DIVERSITY BASED ON HABITATE CHARACTERISTICS ON SUJONO BEACH, BATU BARA DISTRICT, NORTH SUMATERA
}

\author{
Abdul L. Mawardi $1 *$ ), Nurfadilah 2), Elfrida 3), \\ Samudra University \\ email: nurfadilah20178@gmail.com
}

\begin{abstract}
Mollusca is a soft-bodied fauna that is widespread in various habitats including sand, mud and coral substrates. The purpose of this study was to determine the diversity of Mollusca based on habitat characteristics at Sujono Beach, Batu Bara Regency, North Sumatra. This research was conducted at Sujono Beach, Batu Bara Regency, North Sumatra. Sampling was conducted in February 2021. Sampling was carried out by purposive sampling method based on Mollusca habitat. The results showed that the diversity of Mollusca was in the medium category with a value of $H^{\prime}=1.0048$. The most preferred habitat for Mollusca is on sandy substrates, while the habitat that Mollusca does not like is coral substrate.
\end{abstract}

Keywords: Mollusca, Diversity, Characteristics, and Sujono Beach.

\section{INTRODUCTION}

Mollusca is a soft-bodied fauna. One of the Mollusca phyla in Sujono Beach, Batu Bara Regency is Bivalvia and Gastropoda. Mollusca is one of the second largest invertebrates after the phylum Arthropoda which is a soft-shelled animal, there are about 80,000 species belonging to this group that are widely distributed in various habitats, namely land, freshwater and marine waters (Rumbiak et al., 2014). Most of the Mollusca group is widely distributed in various habitats, including sand, mud and coral substrates (Heriansyah et al., 2020). Mollusca is widely used by the community for various purposes, namely food, crafts, and a mixture of animal feed (Gofur, 2003).

\section{RESEARCH METHODS}

This research was conducted at Sujono Beach, Batu Bara Regency, North Sumatra. When the research was conducted in February 2021. Sampling was carried out by purposive sampling method based on the

\section{Data analysis}

\section{Diversity Index (H ')}

Mollusca diversity was analyzed using the Shannon-Wienner $\left(\mathrm{H}^{\prime}\right)$ diversity index formula as follows:

Information:
The spread of Mollusca is influenced by several factors, including habitat, availability of food and substrate found in the Mollusca habitat. The habitat of Mollusca includes sand, mud and coral substrate (Kisman, et, al., 2016). The coastal area is one of the habitats favored by Mollusca. This condition causes the coastal area to get pressure from various activities and phenomena that occur on land and at sea (Ramadhani et al., 2015). This is because this area plays an important role for marine life, especially Mollusca (Marpaung, et al. 2014). The purpose of this study was to determine the diversity of Mollusca based on habitat characteristics at Sujono beach, Batu Bara district, North Sumatra.

characteristics of the mollusca habitat on the beach of Sujono. Sampling was carried out at three stations consisting of sand, mud and coral substrate. The molluscs found were put into a specimen bag, then identified at the PMIPA Laboratory of Samudra University.

$\mathrm{H}$ : Estimator of population diversity pi: Number of individuals of each type $(\mathrm{i}=$ $1,2,3, \ldots)$

$\mathrm{s}$ : Number of types

Criteria

$\mathrm{H}^{\prime}<1$ Low diversity

$1<\mathrm{H}^{\prime}<3$ Moderate diversity

H '> 3 High diversity (Fachrul, 2007). 


\section{Dominance Index (D)}

The dominance of Mollusca was analyzed using the Simpson's dominance index formula as follows:

Where: $\mathrm{Pi}=$ ni $/ \mathrm{N}$

$$
\mathrm{D}=\sum_{i=1}^{s} P \boldsymbol{i}^{2}
$$

\section{RESULTS AND DISCUSSION}

The results found 19 species of Mollusca from 2 classes, namely the Bivalvian class and the Gastropod class found on Sujono beach, Batu Bara Regency, North Sumatra. Mollusca diversity is
Information:

D: Dominance Index ni: Number of individuals of the ith species $\mathrm{N}$ : The total number of individuals Criteria $00.0<\mathrm{C} \leq 0.30$ Low Dominance $0.30<\mathrm{C} \leq 0.60$ Moderate Dominance $0.60<\mathrm{C} \leq 1.00$ High dominance (Fachrul, 2007).

classified as moderate, namely $\mathrm{H}^{\prime}=1.0048$. The overall diversity index of molluscs found at the study site can be seen in table 1 below:

Table 1. Diversity of Mollusca at the research site

\begin{tabular}{clcccc}
\hline No & Species Name & $\begin{array}{c}\text { Total } \\
\text { Number }\end{array}$ & Pi & ln Pi & Pi ln Pi \\
\hline 1 & Anadara granosa & 33 & 0,008 & $-4,8227$ & $-0,0388$ \\
2 & Anadara gubernaculum & 73 & 0,0178 & $-4,0288$ & $-0,0717$ \\
3 & Anadara inaequivalvis & 115 & 0,028 & $-3,5743$ & $-0,1002$ \\
4 & Callista erycina & 59 & 0,0144 & $-4,2417$ & $-0,061$ \\
5 & Callista lilacina & 91 & 0,0222 & $-3,8084$ & $-0,0845$ \\
6 & Turricula javana & 22 & 0,0054 & $-5,2282$ & $-0,028$ \\
7 & Donax faba & 73 & 0,0178 & $-4,0288$ & $-0,0717$ \\
8 & Dosinia dilecta & 41 & 0,01 & $-4,6057$ & $-0,046$ \\
9 & Naticarius hebraeus & 59 & 0,0144 & $-4,2417$ & $-0,061$ \\
10 & Paphila gallus & 48 & 0,0117 & $-4,448$ & $-0,052$ \\
11 & Meretrix meretrix & 83 & 0,0202 & $-3,9004$ & $-0,0789$ \\
12 & Perna viridis & 3280 & 0,7996 & $-0,2236$ & $-0,1788$ \\
13 & Cerithideopsilla alata & 20 & 0,0049 & $-5,3235$ & $-0,026$ \\
14 & Chicoreus capusinus & 5 & 0,0012 & $-6,7098$ & $-0,0082$ \\
15 & Nassrium stolatus & 62 & 0,0151 & $-4,1921$ & $-0,0634$ \\
16 & Pugilina cochlidium & 2 & 0,0005 & $-7,6261$ & $-0,0037$ \\
17 & Turritella terebra & 4 & 0,001 & $-6,9329$ & $-0,0068$ \\
18 & Paphia undulata & 11 & 0,0027 & $-5,9213$ & $-0,0159$ \\
19 & Murex elensis & 5 & 0,0012 & $-6,7098$ & $-0,0082$ \\
\hline \multicolumn{7}{r}{ Amount } & $\mathbf{4 0 8 6}$ & & & $\mathbf{- 1 , 0 0 4 8}$ \\
\hline \multicolumn{7}{r}{ H' = $\sum$ Pi In Pi } & & & & $\mathbf{1 , 0 0 4 8}$ \\
\hline
\end{tabular}


Based on table 1, it can be seen that the overall diversity of molluscs in Sujono Beach, Batu Bara Regency is classified as moderate, namely $\mathrm{H}^{\prime}=1.0048$.
The diversity of molluses when viewed based on research stations can be seen in Figure 1.

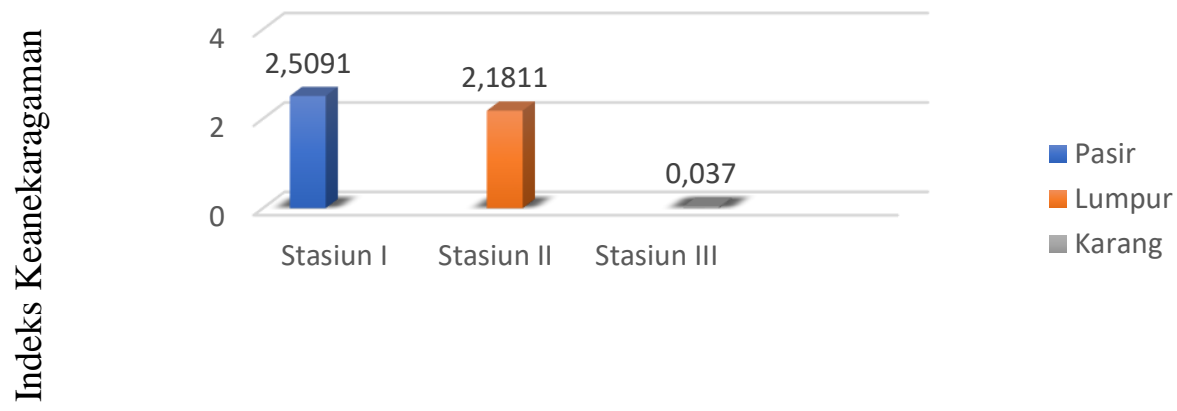

Stasiun Penelitian

Figure 1: Mollusca Diversity Index by Research Station

Based on Figure 1, it can be seen that the highest mollusca diversity index is found in sandy habitats, namely 2.5091 and the lowest habitat is on coral, namely 0.037 .
The characteristics of the Mollusca habitat at Sujono Beach, Batu Bara Regency, North Sumatra based on the substrate can be seen in table 2 below:

Table 2. Habitat Characteristics of Mollusca at the Penreltian location

\begin{tabular}{cll}
\hline No & \multicolumn{1}{c}{ Species Name } & Habitat \\
\hline 1 & Anadara granosa & \\
2 & Anadara gubernaculum & \\
3 & Anadara inaequivalvis & \\
4 & Callista erycina & \\
5 & Callista lilacina & \\
6 & Turricula javana & \\
7 & Donax faba & \\
8 & Dosinia dilecta & \\
9 & Naticarius hebraeus & \\
10 & Paphila gallus & \\
11 & Meretrix meretrix & \\
12 & Nassrium stolatus & \\
13 & Pugilina cochlidium & \\
14 & Turritella terebra & \\
15 & Paphia undulata & \\
16 & Murex elensis & \\
\hline 1 & Anadara granosa & \\
\hline
\end{tabular}




\begin{tabular}{cll}
\hline No & \multicolumn{1}{c}{ Species Name } & Habitat \\
\hline 2 & Anadara gubernaculum & \\
3 & Anadara inaequivalvis & \\
4 & Callista erycina & \\
5 & Callista lilacina & Muddy \\
6 & Donax faba & \\
7 & Dosinia dilecta & \\
8 & Paphila gallus & \\
9 & Meretrix meretrix & Coral \\
10 & Chicoreus capusinus & \\
\hline 1 & Perna viridis & \\
2 & Cerithideopsilla alata &
\end{tabular}

Based on Table 2. it can be seen that the most preferred mollusc habitat is in the habitat with sandy substrate found 16 mollusc species, while the lowest habitat is found in coral substrate only 2 mollusc species are found. The physical and chemical parameters measured include water temperature and water $\mathrm{pH}$. The water temperature ranges from $27-30^{\circ} \mathrm{C}$, while the $\mathrm{pH}$ of the water ranges from 7.0 to 7.8 . The physical and chemical parameters of the environment can be seen in Table 2 below:

Table 3. Physical and chemical parameters at the research location

\begin{tabular}{llll}
\hline \multicolumn{1}{c}{ Parameter } & \multicolumn{3}{c}{ Research Station } \\
& Sandy & Muddy & Coral \\
\hline Water Temperature & $27^{\circ} \mathrm{C}$ & $30^{\circ} \mathrm{C}$ & $28^{\circ} \mathrm{C}$ \\
Water pH & 7,0 & 7,8 & 7,4 \\
\hline
\end{tabular}

The average temperature measurement at each station is around $27^{\circ} \mathrm{C}-30^{\circ} \mathrm{C}$. Station I have a temperature value of $27^{\circ} \mathrm{C}$ which is the lowest temperature, while the highest temperature value at station II is $30^{\circ} \mathrm{C}$. The average $\mathrm{pH}$ measurement ranges from 7-8, station I has a $\mathrm{pH}$ value of 7.0 which is the lowest value, station II has a $\mathrm{pH}$ value of 7.8 , while station III has a $\mathrm{pH}$ value of 7.4 , among the three stations, station II yeng has the highest $\mathrm{pH}$ value. The condition of the substrate at Station I is sandy, Station II is muddy, and Station III is coral.

Based on the results of research conducted at Sujono Beach, Batu Bara Regency, it was found that there were 2 classes of Mollusca, namely Bivalvia and Gastropods. The diversity index of Mollusca at the research location is classified as moderate category $\mathrm{H}=1.0048$ which indicates that the mollusca habitat there is in a balanced state and the substrate conditions are not easily changed due to relatively small environmental influences. This shows that the mollusca species are diverse and varied (Ikramullah, et, al 2017).

Based on the location of the research, the highest diversity of Mollusca is at research location $\mathrm{I}$, which is in a sandy place with a moderate diversity index $\mathrm{H}^{\prime}=2.5091$, According to Ikramullah, et., al (2017) this shows Mollusca habitat is in good condition and not polluted. while the lowest diversity of mollusca species was found at research location III, namely in the reefs with a low diversity index $\mathrm{H}^{\prime}=0,037$. According to Suyasa, et., al (2010) that in ecosystems that have low diversity due to physical stress and unexpected external disturbances, namely physical components such as weather, water temperature, water $\mathrm{pH}$, limiting chemical factors, pollution and so on. 
The most dominant mollusca $\mathrm{D}=$ 0.6443915 , namely perna viridis is classified as high dominance, according to Syukri, (2017) this is because the substrate supports the growth of the mollusca. While the lowest dominance index is found at $\mathrm{D}=0.000025$, which is classified as the lowest, namely Pugilina cochlidium on a craggy substrate. According to Tyas, (2015) this is because the habitat and several other factors that can affect the growth of Mollusca, namely temperature, $\mathrm{pH}$ and substrate conditions have an impact on the growth and diversity of Mollusca found at each station have different numbers and diversity, due to environmental parameters and Substrate conditions at each station are different which can affect the growth of Mollusca. Besides habitat factors, in addition, the habitat factors, temperature and $\mathrm{pH}$ factors in Sujono Beach, Batu Bara Regency can also inhibit the growth of molluscs, where the temperature at the research location ranges from 25-30 ${ }^{\circ} \mathrm{C}$. between 25-30 ${ }^{\circ} \mathrm{C}$. According to (Suwignyo et, all., 1981; Sukarno., 1988; Agustini, 2016) the optimal temperature for mollusk life is in the range of 20-36 ${ }^{\circ}$ C. If the water temperature changes in a habitat, it will change its composition and can result in death for marine life including Mollusca (Syafikri, 2008; Rizal, et., Al, 2013). Changes in temperature outside the optimum limit will provide an overview of the decline in the growth rate and production of organisms (Islami, 2013: 5). According to Odum (1993) $\mathrm{pH}$ is a limiting factor for an organism, waters with a very high or low $\mathrm{pH}$ will affect the survival of the organisms that live in it, such as molluscs. The $\mathrm{pH}$ at the study sites ranged from 7.0 to 7.4. According

\section{CONCLUSION}

The diversity of Mollusca in Sujono Beach, Batu Bara Regency, North Sumatra is in the medium category with a value of $\mathrm{H}$

\section{REFERENCE}

Fachrul, MF 2007. Bioecological Sampling Methods. Earth Literacy. Jakarta.

Gofur, A., 2003. The Effect of Feeding Kupang (Musculita Seannhausia) Flour on Productivity and Heavy to Wijayanti (2007), the $\mathrm{pH}$ value of the waters is an important parameter in monitoring water quality. The temperature death of organisms is more often caused by a low $\mathrm{pH}$ than a high $\mathrm{pH}$. Overall, physics and chemistry in the research location can support the life and growth of Mollusca in the Sujono Beach Area, Batu Bara Regency, the $\mathrm{pH}$ value is in the range of $5.7-8.4$, which is still suitable for mollusca life. Temperature mortality of organisms is more often the result of a low $\mathrm{pH}$ than a high $\mathrm{pH}$. Overall, the physics and chemistry found in the research location can support the life and growth of Mollusca in the Sujono Beach Area, Batu Bara Regency, the $\mathrm{pH}$ value is in the range of $5.7-8.4$, which is still suitable for mollusca life. Temperature mortality of organisms is more often the result of a low $\mathrm{pH}$ than a high $\mathrm{pH}$. Overall, physics and chemistry in the research location can support the life and growth of Mollusca in the Sujono Beach Area, Batu Bara Regency, the $\mathrm{pH}$ value is in the range of $5.7-8.4$, which is still suitable for mollusca life.

Based on the results of research conducted at Sujono Beach, Batu Bara Regency, 2 classes were found, 19 species. The two classes consist of Bivalves and Gastropods. Of the Bivalvia class there are 11 species, namely: Anadara granosa, Anadara gubernaculum, Anadara inaequivalvis, Callista erycina, Callista lilacina, Donax faba, Dosinia dilecta, Pahila gallus, Meretrix meretrix, Paphila undulata, and Perna viridis, and 8 species of gastropods: Cerithideopsilla alata, Murex elensis, Chicoreus capusinus, Nassrium stolatus, Pugilina cochlidium, Turritella terebra, Turricula javana and Naticarium hebraeus.

$'=1.0048$. The most preferred habitat for Mollusca is on sandy substrates, while the less preferred habitat is on coral substrates.

Metal Content in Mojosari Duck Meat. Postgraduate Journal of Bioscience. 5 (2).

Heriansyah. Hermi, A. Sarong, AM Irmah, M. 2020. Habitat Characteristics of Seashell Species in Coastal Areas of 
Aceh Jaya Regency, Aceh Province. Journal of aceh aquatic science. 4(1): 41-47.

Ikramullah. Sarong, A. M, Dewiyanti, I. 2017. Abundance and Diversity of Gastropods and Bivalves in Gampong Ie Masen Mangrove Ecosystem, Muara Tiga District, Pidie Regency. Unsyiah Marine and Fisheries Student Scientific Journal. 2 (4): 497-503. ISSN. 2527-6395.

Kisman. DH, Ramadan. A, yourself. M. 2016. Types and Diversity of Bivalves in the Sea of Maputi Island, Sojol District, Donggala Regency, and Their Use as a Media for Learning Biology. e-jipbiol. 4 (1): 1-14. ISSN. 4628-1794.

Marpaung. FA A, Yasir. I, Ukkas. M. 2014. Diversity of Macrozoobenthos in the Silvofishery Mangrove Ecosystem and Natural Mangroves in the Boe Beach Ecosystem, Takalar Regency, South Sulawesi. Bonorowo Wetlands. 4 (1): 1-11. ISSN. 20882475.

Rumbiak, Alfrina et al. 2014. "Morphometric Characteristics and Condition Factors of Totok Shells (Polymesoda Erosa) in Mangrove Forest, Nusajaya Village, South Waslei District, East Halmahera Regency, North Maluku", Platax Scientific Journal. 2 (3): 71-76.

Ruswahyuni, 2010. Population and diversity of macrobenthos in closed and open waters in Awur Bay, Jepara. Fisheries and Marine Scientific Journal. 2 (1): 11-20.

Suyasa, I. N, Moch, Nurhudah and Sinung, R. 2010. Aquatic ecology. Publisher: STP Press, Jakarta. 41-55 p.

Syukri, J, Sarong, A. M, Purnama, S. 2017. Dominance of Macrozoobenthos in the Kuala Pidie Area, Sigli City District, Pidie Regency. Unsyiah Marine and Fisheries Student Scientific Journal. 2 (3): 349-355. ISSN. 2527-6395.
Tyas, M. W and Joko, W. 2015. Identification of Gastropods in the Sub-watershed of the Tributary of Gandong, Kerik Takeran Village. Journal of Florea. 2 (2): 52-57. 